\title{
Research on Aesthetic Value of Twelve Ancient Songs of Hani People's
}

\section{Ancient Songs}

\author{
Xin Wang ${ }^{1, \text { a }}$ \\ ${ }^{1}$ School of Music of Honghe University, Mengzi, Yunnan, China, 661100 \\ ${ }^{\mathrm{a}}$ email
}

Keywords: Twelve Ancient Songs, Aesthetics, Content, Form

\begin{abstract}
As the most famous Hani ancient songs, the Twelve Ancient Songs' aesthetic value has not received an adequate attention. In fact, these ancient songs not only accumulated rich experience for the aesthetics of the Hani nationality literature and art, but also provide the continuing art nutrients. The contrast of the cognition and reality is unfavorable for the development of the art of Hani people and the Chinese nation. In terms of content, the creation of this ancient song of the magnificent complex world of imagination and characters is richly adorned or plainly dressed; in terms of form, these ancient songs embody the narrative style and take it leisurely.
\end{abstract}

Twelve Ancient Songs are the famous Hani ancient songs sung by generations. The Hani people's long-term collective creation, concentrated record of the Hani people distant ethnic cultural memory and the unique national life style, known as the Hani artistic encyclopedia" and "primitive rap art" living fossil. In terms of content, the creation of this ancient song of the magnificent complex world of imagination and characters is richly adorned or plainly dressed; in terms of form, these ancient songs embody the narrative style and take it leisurely.

\section{Spectacular Imaginary World}

The Hani people holding "animism" thought, not only is human, animal and plant are the same life and feeling, soul and consciousness. This is the Hani people's view of the world, is the philosophical foundation of ancient song. Accordingly, "nest" Twelve ancient songs constructed a lumpy, extraordinary as if done by the spirits world of imagination.

The "smoke" the Howard also known as "God's song", tells the story of the Hani nationality myth. With other nationalities such as Han, Miao nationality myth, the Hani myth in the world, is also one of the original chaotic, the difference is the creation of the world feat is accomplished by a female goldfish. "A mother's right fin fish, black fog fan is light blue day out....... It's a left fin, the vast waters fan ground revealed......" In addition to the creation of the world, Hani original God making movement is completed by the goldfish, "and who, and the God of fish mother bear, from the neck from the inside, a shake out of the great God, first is the God of the sun is out after Yoro, the moon god about white." On the back of a fish shake, this time have two great God, this is the God of gods and Omar, mime. Close to the waist and tail, to jump out of a God, they are famous people of God, the man called smoke butterfly, a girl named Mary butterfly. The fish mother broad tail, hiding a God, he is the strongest and lofty." This strange imagination fills the whole ancient song, "Russian" made in the dense color day to use green stone, so will the sky blue, but also left eye in the sky, the stars will blink, makes the need to build a bellows, so people can breathe. 
Marx believes that the myth is "through people's imagination in a way not consciously processed natural and social form itself, if the myth itself is a kind of fantasy and imagination, so the Hani myth is very close to the real life, seemingly Joystiq, in fact, have very strong realistic targeted, has a powerful explanation for real life. This corresponds with the narrative of the human world, Hani ancient song "this is the" nest of Huo comparable to the myth of the strong imagination.

In the "straight faced" in three kinds of jazz, is capable of smoke dust from the great God three blocks long out of the ground, they were in charge of the stockade security, sacrifice and tools. When these jobs are incompetent to control, "the same as the chicken coop, we did not rest, three people left," as mad as a mad dog bites. It became like the elderly eat their offspring was the old man's daughter and son-in-law snake plan to surrender. In this magical world, "put on the cloud pants, earth was not cold, the pig is the great God Yansha circle master, stone crab and clam is guardian of water water, who is out of the ground, the frog can" sit on the ridge, the rainbow is the king of the mind ". Turn the. The eldest son of the tiger tower's ten years of a child, the two son of long eagle flies in the sky, is because of impiety and suffered a mother's curse. The whimsy and so on, can be found everywhere, this is not superfluous for.

The Hani people through imagination construct a magical world of magnificent complex, lustrous and dazzling. Man, God, ghosts and beasts, birds, life and death, nothing needed is lacking. Disease, old, disabled, confused. The world will fly, will run, will climb will twist, which can find the source in this world, every custom. Every phenomenon can be found in the world.

\section{Various Group Characters}

Impacted by the profound effect on the world view of the basic spirit of the universe, in the eyes of the Hani people, not only for the emotional activities of all the people, to the ghost, to the birds and insects have the ability of emotional feelings and life experience, there is need for emotional expression. Therefore, in the "nest" Twelve ancient songs created the magic world, various species of heaven, with lively emotions and distinctive character, they are a group of personality characteristics of the artistic image, not only Hani as the object of man's practice and reflects the state of existence, but also as organic a formation mechanism of human life of Hani's personality, in the role of Hani personality plays an important and in the inheritance. It is the unique characteristics of humanity in the image of the world full of strong artistic appeal to "nest" such an important function Twelve ancient songs. But this ancient song image is not all clear, but in the story outline were dyed and different degree according to the needs of the story. Therefore, some image can be dressed up, and some image only as a passerby. This method makes the image system "richly adorned or plainly dressed" with rich Twelve ancient songs nest and typical.

Magang $\mathrm{CuO} \mathrm{CuO}$ dense was born, the character will be revealed. Unlike other gods, it is mighty but grumpy, fiddle with the fish tail Niang got a murky sky over a dark earth like a playful child. Later attracted three other gods of discontent, lofty and dense bravely fight against them, heaven and earth are their battlefield. This image and the general sense of God is clearly not the same, although it has the power of God, but there is no perfect God, and filled with the weakness of human nature, and even the child's innocence. Also because of this, it's three to elder brother elder sister each have top of the clergy, but it has no. The headman, and craftsmen as the three people of the Hani nationality have the same God, but they also have the distinctive feature of human nature. When Hani advanced rules were destroyed, three people were incompetent people holding positions, they ran away. They are Russian Wu Luo mother side, side heartbroken while working. After about seven baskets of Hani people good, only to change mind back to the walled in. In the story of the outline, the three have the ability. The heart of the delicate and good image has been the focus of 
the presentation. In this process, also presented the superficial type leisurely frog image, hard-working bee image, and rectifies the Hani people image.

\section{Perfect Structural Form}

As a kind of artistic text for the concert, "nest" Twelve ancient songs organization form is carefully designed, its structure is very large and very clear hierarchy and logical clues.

On the level of structure, "nest" Twelve ancient songs is one paragraph as a basic unit of these paragraphs, or long or short, but they are just as confused with errors and omission, semantic units exist and does not have a complete story, even as each other, one by one according to the clues of the development of beads consisting of a line of a complete section of the. Every day they all have a theme, have a certain degree of independence, but also exists as an organic part of a chapter, such as the three day of birth, about people escape and regression together form a "straight faced Jue" this chapter, respectively, about twelve months of the twelve different customs ancient song together constitute the "nest" this chapter Maceniguo Qihoo.

But between these units at the basic level in order to construct the relation is not arbitrary, there is an inherent logic between them. This is the "nest" of the logical structure of Twelve ancient songs. As in "the smoke of this hall" about the ancient spirit of the movement, the close to the "Russian Color Secret", "look up cow color" two chapters, about the creation of heaven and earth and the movement of heaven and earth. God is in place, the creation, movement made with vigour and vitality, build sports wasteland farming village settlement movement once launched, it will have a "butterfly, butterfly, Albert," Butterfly "Hunan", "the nest" chapter three ancestral progenitor. The six chapter "again in the" nest of the hall while not in accordance with the development of the sequence structure of the story, but each chapter also exists between the clear logical relationship, as Mr. Zhang Hongzhen said: "from the" straight faced "to" sudden "Prince ang," from the Qihoo "to" nest Maceniguo so dense Kema color ", from" Su Xueben "to" suck, "Luo, all telling the ancient....... Hani ancient song "song" (this is a nest of the Huo) department rules for the Hani family to create a peaceful epic of creation." and "this" and "smoke the Huo Huo" the nest as "God song" and "song", apparently in the logical structure inheritance relationship exists, this is not to say.

Cooperate with each other in hierarchical structure and logic structure, showing the "subtlety" Twelve ancient songs nest in the structure form, the structure form of the Zhulianbihe itself is a kind of aesthetic paradigm, worthy of deep mining.

\section{Unhurried Narrative Style}

Twelve ancient songs narrative has distinctive features, humorous language and elegance, whether narrative or descriptive, cannot loose not tight, not fast nor slow, showing a poised style. The pen with ink often transparent, rarely stay in a wanton rendering. Although the image is thick is thin, with a shallow depth, and the difference is through the story gradually formed naturally, appear many times the image there is a natural makeup color, while most of the image is slightly tinted then swings. The formation of this narrative style, largely due to "nest" Twelve ancient songs exists as a text of rap art, is not the original creation of the literati crafted.

"Each chapter" often "the nest Twelve ancient songs SA - SA - in accordance with the" or as a sentence or line to "talk" or "listen" caused by the story, which create a soothing atmosphere of pouring. And often through the explanation of a simple outline to show the most, is completed in the narrative process in a single line, occasionally mixed with Socratic dialogue, witty sayings or 
strange analogy, the story meanders. "Listen, not the Suolie July Hani circle, big pig to sleep, the slope of the cattle to fall...... Who taught the Hani Suolie? Hani is the most beautiful girl Mei cuo......" "Nest" Twelve ancient songs filled with this soothing mood.

Even if is the description of tense scenes, "nest" Twelve ancient songs tend to be dry, the secret lies in the use of rhetorical repetition and parallelism to change the narrative rhythm. For example, "go to the! Be gone! Escaped! The headman horse run, in the days when escape, is in a sheep one day, craftsmen escape, the monkey is in a day. Ran away! Escaped! Hani fled in a centralized headman, Hani concentrated on a pile of escape, Hani focused on a group of artisans to escape!" This section through repetition and parallelism will be able to escape the scene rendering is very tense, but because the headman, and artisans were narrative, creates semantic repeatedly, which greatly slowed the text semantic rhythm, that is to say, the tension in the speed or the flow, the information content the expression is very small, which formed a poised narrative style. "Nest" in the treatment of Twelve ancient songs when tense plot is used in this way.

As a typical representative of Hani ancient song, "the nest" Twelve ancient songs artistic achievement is obvious to people, the construction of the rich imagination of the magical world, and many vivid and unique image of the man of God, is the national literature and art provides valuable soil nutrients for the development of the art of the Hani nationality. The "nest" structure Twelve ancient songs precision and the unique narrative style is not only for Hani has accumulated rich artistic experience, but also provides a good example for other ethnic art, is a new inspiration to China's literary and artistic creation. But the "nest" of the aesthetic value of Twelve ancient songs is far more than the above aspects, we should be more broadly in this work more in-depth analysis of aesthetics, which is not only a blessing, blessing is the country.

\section{Acknowledgements}

This research is the periodical result of the projcet supported by National Social Science Foundation in 2014 (Grant No. 14CZX053). The name of the project is "Aesthetics of Hani People and Development of Cultural Creative Industry”.

\section{References}

[1] Lyu Junmei, Journal of Honghe University, Vol. 11 (2013) No 3, p.23-25

[2] Yan Huoqi, Li Qi, Studies of Ethnic Literature, Vol. 26 (2008) No 2, p. 123-130

[3] Qian Yechun, Studies of Ethnic Literature, Vol. 28 (2010) No 2, p. 132-137

[4] Wang Dong, Hu Wenqian, Tang Yanan, Modern Society, Vol. 25 (2011) No 4, p. 112-113 